\title{
ESTIMATION OF MORPHOMETRIC PARAMETERS AND RUNOFF USING RS \& GIS TECHNIQUES
}

\author{
Shrudha. V. K' ${ }^{1}$ Hafeezunnisa ${ }^{2}$ \\ ${ }^{I}$ Assistant Professor, Rajarajeshwari College of Engineering Bangalore \\ ${ }^{2}$ Assistant Engineer, WRDO Bangalore Govt of Karnataka
}

\begin{abstract}
Land and water are the two vital natural resources, the optimal management of these resources with minimum adverse environmental impact are essential not only for sustainable development but also for human survival. Satellite remote sensing with geographic information system has a pragmatic approach to map and generate spatial input layers of predicting response behavior and yield of watershed. Hence, in the present study an attempt has been made to understand the hydrological process of the catchment at the watershed level by drawing the inferences from moprhometric analysis and runoff. The study area chosen for the present study is Yagachi catchment situated in Chickamaglur and Hassan district lies geographically at a longitude 7552'08.77” E and $13^{\circ} 10^{\prime} 50.77^{\prime \prime N}$ latitude. It covers an area of 559.493 Sq.km. Morphometric analysis is carried out to estimate morphometric parameters at Micro-watershed to understand the hydrological response of the catchment at the Micro-watershed level. Daily runoff is estimated using USDA SCS curve number model for a period of 10 years from 2001 to 2010. The rainfall runoff relationship of the study shows there is a positive correlation.
\end{abstract}

Keywords: morphometric analysis, runoff, remote sensing and GIS, SCS - method $* * *$

\section{INTRODUCTION}

In recent years, there has been a marked increase in the level of interest towards watershed approach. A watershed is an area from which runoff resulting from precipitation flows past a single point into large streams, rivers, lakes or oceans. Advances in computational power, growing availability of spatial data have made it possible to predict the runoff accurately. One of the objectives of the study is to draw inferences from morphometric analysis and check with the runoff estimated using SCS curve number model. Quantitative description of the catchment geometry requires measurement of linear features, gradient of channel network and contributing slope of the drainage basin. For this, the remote sensing techniques using satellite images and digital database using geographic information system plays a major role in analyzing the catchment parameters and its effect on runoff.

\section{STUDY AREA:}

The study area is Yagachi catchment situated in Chickamaglur and Hassan district lies geographically at a longitude $75^{\circ} 52^{\prime} 08.77^{\prime \prime} \mathrm{E}$ and $13^{\circ} 10^{\prime} 50.77^{\prime} \mathrm{N}$ latitude. It covers an area of $559.493 \mathrm{Sq} . \mathrm{km}$. Fig. 1 shows the location map of the study area and 20 Micro-watersheds (Fig. 2) are delineated based on topography and drainage pattern to understand hydrological process of the catchment at the watershed level. The drainage pattern is coarse texture and dendritic to sub-dendritic drainage pattern at catchment level and coarse to very coarse drainage texture at Micro-watersheds level. The annual rainfall varies from a maximum of $2301 \mathrm{~mm}$ to a minimum of $1233 \mathrm{~mm}$ with a mean annual rainfall of $1921.5 \mathrm{~mm}$. The principal soil types are red loamy and red clayey soils

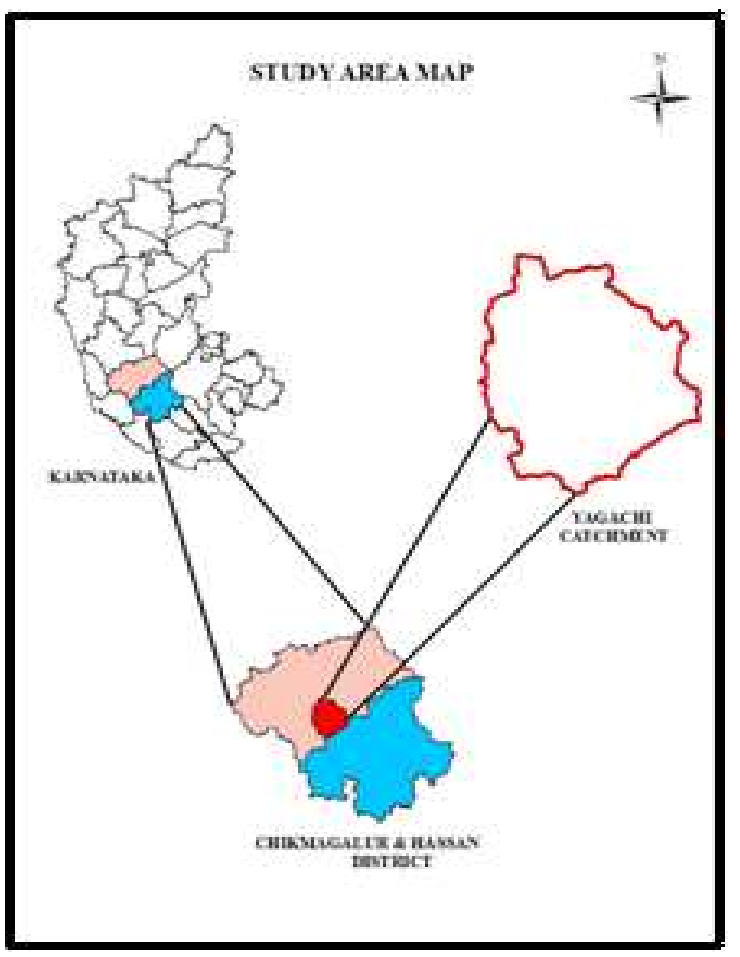

Fig. 1 Location map of study area 


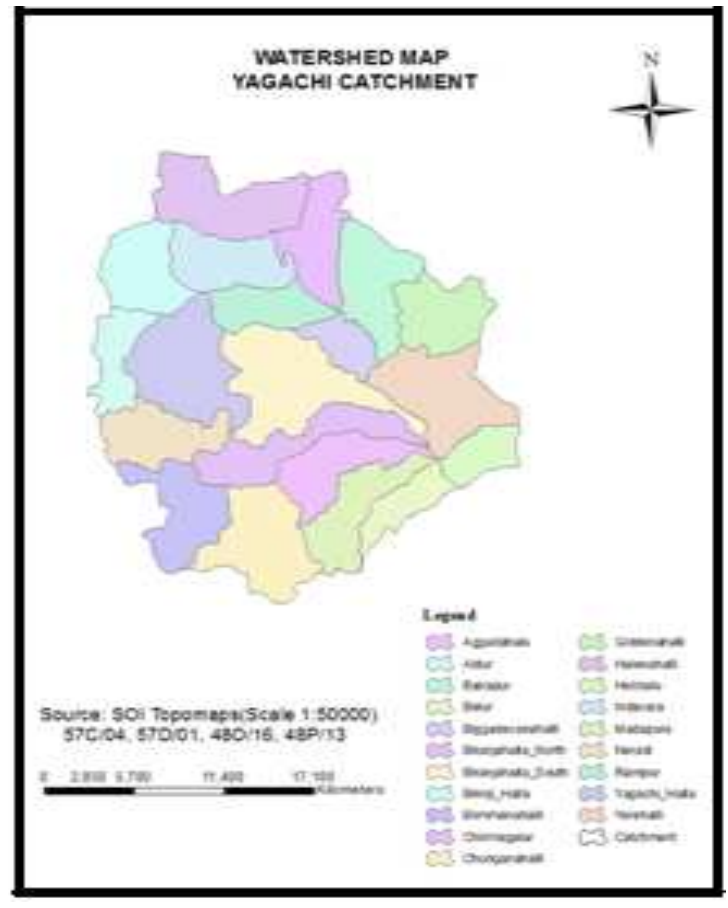

Fig. 2 Micro Watershed map of study area

\section{DATA USED}

The Survey of India (SOI) topomap nos. 57C /04, 57D/01, $48 \mathrm{O} / 16,48 \mathrm{P} / 13$ topomaps on 1:50000 scale. are used for delineation of catchment, Micro-watersheds and drainage map. IRS-1D LISS III 15th December, 2001 and March 15th, 2001 are used for updating drainage map and preparation of thematic maps. Daily rainfall data for runoff estimation on daily basis is considered.

\section{MORPHOMETRIC ANALYSIS:}

Morphometric analysis provides quantitative description of the basin geometry to understand initial slope or inequalities in the rock hardness, structural controls, geological and geomorphic history of drainage basin [Strahler, 1964]. One of the advantages of morphometric analysis is that many of the watershed parameters derived are in the form of ratios, dimensionless numbers, thus providing an effective comparison irrespective of scale [Krishnamurthy et al., 1996]. The morphometric analysis is the measurement of linear aspect, areal and relief aspects of drainage basin. The concept of stream ordering has been outlined by [Horton 1932] and later amended by [Strahler 1964] to decrease the subjectivity of drainage analysis. The highest order assigned is 6th order and hence designated as sixth order catchment. Fig. 3 shows the stream order map. Moprhomteric characteristics and parameters estimated are tabulated in Table 1 and 2 respectively.

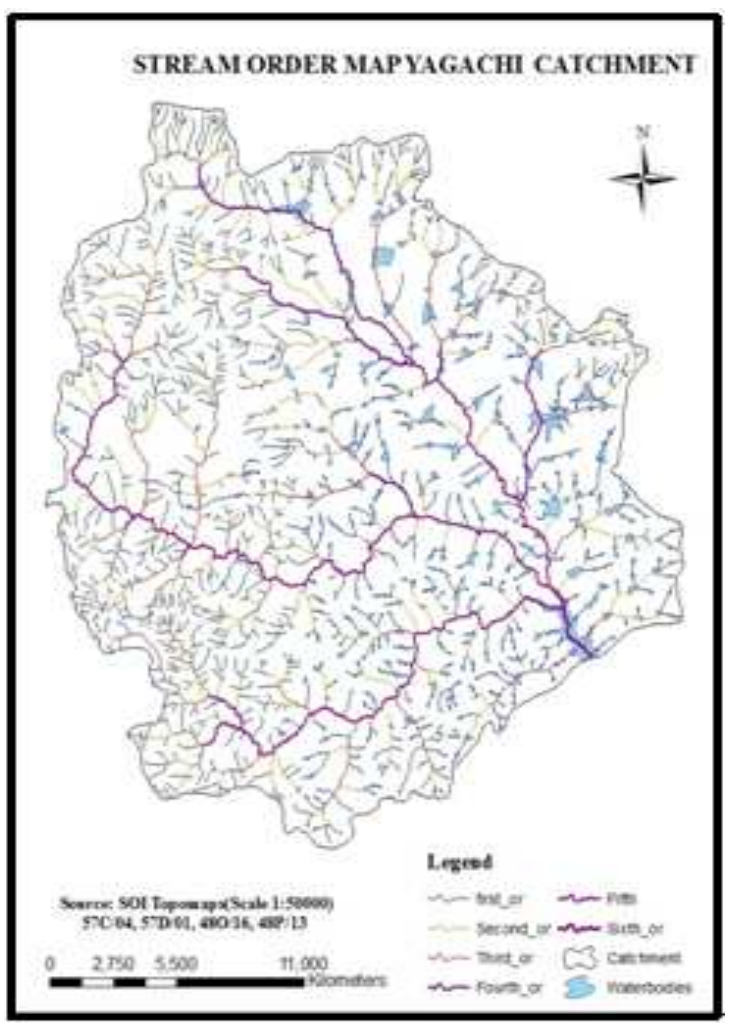

Fig. 3 Stream order map 
Table.1 Morphometric Characteristic of Yagachi catchment

\begin{tabular}{|c|c|c|c|c|c|c|c|c|}
\hline $\begin{array}{l}\text { Stream } \\
\text { order }\end{array}$ & $\begin{array}{l}\text { No of } \\
\text { segments } \\
(\mathrm{Nu})\end{array}$ & $\begin{array}{l}\text { Total } \\
\text { Stream } \\
\text { length } \\
" \mathrm{~L} " \\
(\mathrm{Km}) \\
\end{array}$ & $\begin{array}{l}\text { Bifurcation } \\
\text { ratio }(\mathrm{Rb})\end{array}$ & $\begin{array}{l}\text { Mean } \\
\text { length Lu } \\
(\mathrm{Km})\end{array}$ & $\begin{array}{l}\text { Cumulative } \\
\text { length } \\
(\mathrm{Km})\end{array}$ & $\begin{array}{l}\text { Cumulative } \\
\text { No of } \\
\text { Segments }\end{array}$ & $\begin{array}{l}\text { Stream } \\
\text { Length } \\
\text { Ratio } \\
(\mathrm{RL}= \\
\mathrm{Lu} /(\mathrm{Lu}- \\
1)) \\
\end{array}$ & $\begin{array}{l}\text { Drainage } \\
\text { density }\end{array}$ \\
\hline 1 & 1301 & 551.85 & 6.706 & 0.424 & 551.85 & 1301 & - & \multirow{6}{*}{0.986} \\
\hline 2 & 194 & 100.9 & 4.512 & 0.52 & 652.75 & 1495 & 1.226 & \\
\hline 3 & 43 & 19.17 & 4.3 & 0.446 & 671.92 & 1538 & 0.857 & \\
\hline 4 & 10 & 6.308 & 3.333 & 0.631 & 678.23 & 1548 & 1.415 & \\
\hline 5 & 3 & 1.879 & 3 & 0.626 & 680.11 & 1551 & 0.993 & \\
\hline 6 & 1 & 3.573 & - & 3.573 & 683.68 & 1552 & 5.705 & \\
\hline
\end{tabular}

Table.2 Morphometric Parameters of Yagachi Catchment

\begin{tabular}{|l|l|l|l|}
\hline \multicolumn{5}{|l}{ Different Morphometric Parameter of Yagachi Catchment } \\
\hline S1 no & Watershed parameters & Units & Values \\
\hline 1 & Watershed area & $\mathrm{Km}^{2}$ & 559.49 \\
\hline 2 & Perimeter of Watershed & $\mathrm{Km}$ & 114.99 \\
\hline 3 & Watershed highest order & $\mathrm{No}$ & 6 \\
\hline 4 & Maximum length of Watershed & $\mathrm{Km}$ & 31.83 \\
\hline 5 & Maximum width of Watershed & $\mathrm{Km}$ & 28.4 \\
\hline 6 & Form factor & & 0.55 \\
\hline 7 & Shape factor & & 1.81 \\
\hline 8 & Cumulative stream segment & $\mathrm{Km}$ & 1552 \\
\hline 9 & Cumulative stream length & $\mathrm{Km}$ & 683.68 \\
\hline 10 & Stream frequency & $\mathrm{No} / \mathrm{Km}^{2}$ & 2.774 \\
\hline 11 & Drainage density & $\mathrm{Km} / \mathrm{Km}^{2}$ & 1.222 \\
\hline 12 & Constant of Channel maintenance & $\mathrm{Km} / \mathrm{Km}$ & 0.818 \\
\hline 13 & Length of Overland flow & $\mathrm{Km}$ & 0.67 \\
\hline 14 & Bifurcation ratio & & 0.999 \\
\hline 15 & Stream length ratio & & 2.277 \\
\hline 16 & Circularity ratio & & 0.531 \\
\hline 17 & Elongation ratio & & 0.593 \\
\hline 18 & Compactness coefficient & & 1.372 \\
\hline 19 & Watershed relief ratio & & 0.024 \\
\hline 20 & Relative relief ratio & & 0.628 \\
\hline 21 & Ruggedness number & & \\
\hline & & & \\
\hline
\end{tabular}




\section{RUNOFF ESTIMATION:}

Reliable prediction of quantity and rate of runoff from land surface into streams and rivers is difficult and time consuming. Conventional models for prediction of river discharge require considerable hydrological and metrological data. Collection of these data is expensive, time consuming and a difficult process. Remote sensing technology has augmented the conventional methods to a great extent in rainfall-runoff studies. The curve number method (Soil Conservation Services, SCS, 1972) also known as the hydrologic soil cover complex method is a versatile and widely used procedure for runoff estimation for ungauged watersheds. McCuen (1982); Stube and Johnston (1990); Ramaprasad et al. (1993); Ponce and Hawkins (1996) Nageshwar Rao (2010) have demonstrated the use of SCS curve number model for runoff estimation. This method include several important properties of watershed namely soil permeability, land use and antecedent soil moisture condition. The SCS curve number method is based on the water balance equation and developed on two fundamental hypothesis. The first Hypothesis is expressed as;

$$
\mathrm{Q} /\left(\mathrm{P}-\mathrm{I}_{\mathrm{a}}\right)=\mathrm{F} / \mathrm{S}
$$

where $\mathrm{Q}$ is the runoff, $\mathrm{P}$ is the rainfall and $\mathrm{F}$ is the actual infiltration and it is the difference between the potential and accumulated runoff. Ia is the initial abstraction, which represent all the losses before the runoff begins. $S$ is the potential infiltration after the runoff begins $(S>F)$. The second hypothesis is expressed as ;
Substituting $F$ in eq(1) and rewriting we get;

$$
\mathrm{Q}=\left(\mathrm{P}-\mathrm{I}_{\mathrm{a}}\right)^{2 /}\left(\mathrm{P}-\mathrm{I}_{\mathrm{a}}\right)+\mathrm{S}
$$

Where

$$
\mathrm{I}_{\mathrm{A}=0.2 \mathrm{~S}}
$$

$\mathrm{S}$ is spatially distributed variable defined As

$$
S=(25400 / \mathrm{CN})-254
$$

Curve Number Index $(\mathrm{CN})$ is a relative measure of retention of water by a given soil vegetation complex and takes on values from 0 to 100. It is a combination of a hydrologic soil group and antecedent moisture conditions. The Curve Number values for AMC-I and AMC-III are obtained from AMC-II [Ven Te Chow, 1982] by the method of conservation. The empirical equations used for estimation of $\mathrm{CN} 1$ and $\mathrm{CN} 3$ are as follows

$$
\begin{aligned}
& \mathrm{CN}_{1}=\mathrm{CN}_{2} /\left(2.281-0.0128 \mathrm{CN}_{2}\right) \\
& \mathrm{CN}_{3}=\mathrm{CN}_{2} /\left(0.427+0.00573 \mathrm{CN}_{2}\right)
\end{aligned}
$$

The curve number are assigned on by polygon wise by overlaying the land use/land cover map and hydrological map

$$
\mathrm{F}=\left(\mathrm{P}-\mathrm{I}_{\mathrm{a}}\right)-\mathrm{Q}
$$

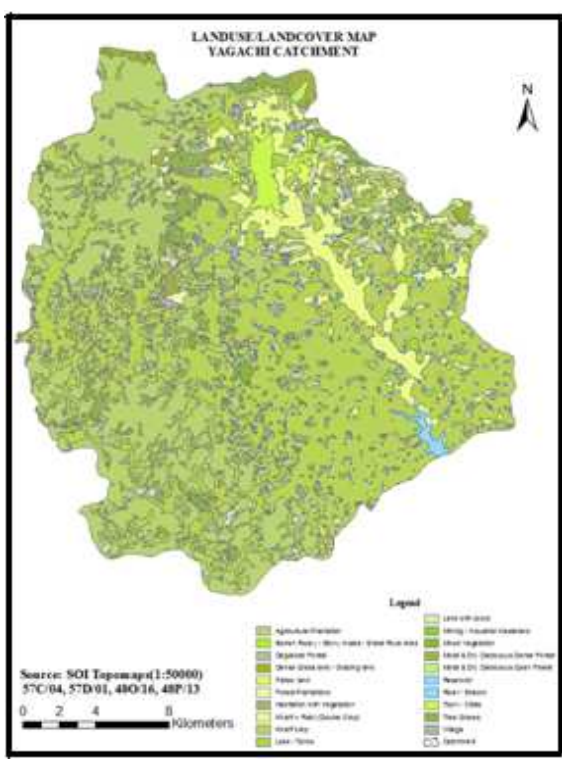

Fig. 4 Land use/Land Cover Map

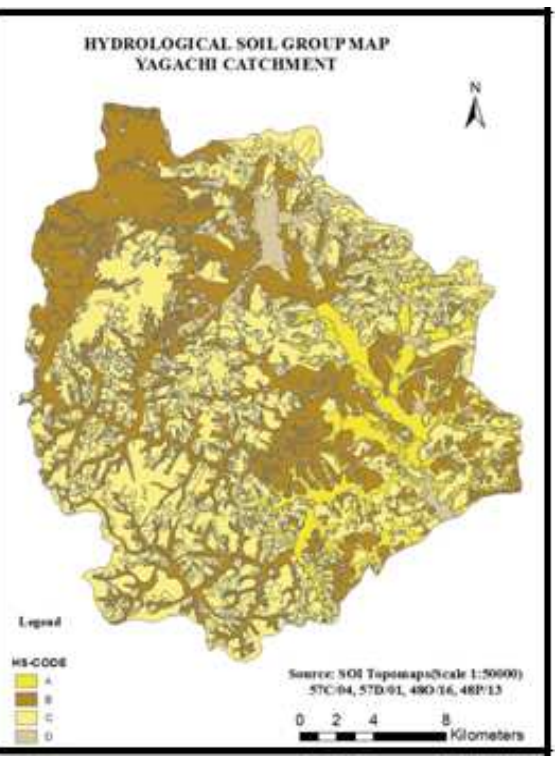

Fig. 5 Hydrological Soil Group map 


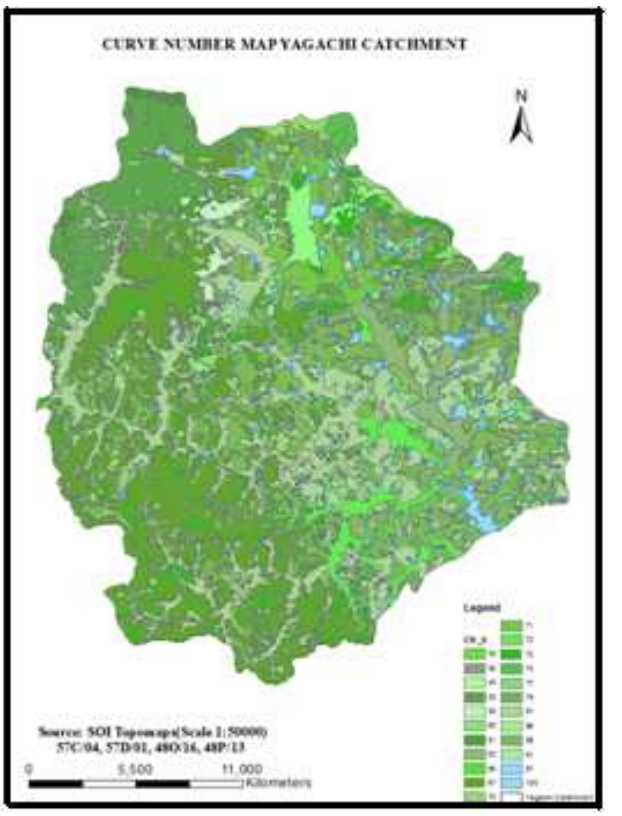

Fig. 6 Curve Number map

Fig. 6 shows the curve number map of the catchment area. The daily runoff on watershed wise is estimated for a period of 10 years from 2001 to 2010 by concentrating all the three AMC conditions with daily rainfall data.

\section{RESULTS \& DISCUSSION:}

The term bifurcation ratio $(\mathrm{Rb})$ is used to express the ratio of number of streams of any given order to the ratio of streams in the next higher order. It is observed that, the bifurcation ratio is less than 5 indicating that the catchment is structurally controlled or the structural disturbance is less. But, when individual Micro-watersheds are analyzed higher bifurcation ratio is noted in most of the Micro-watersheds which indicates structural disturbance and head ward erosion. The bifurcation ratio of all micro-watersheds indicates normal category. The presence of low drainage density suggests that it has highly permeable sub-soil and moderate to coarse drainage texture. The value of stream frequency for all the Micro-watershed varies from 1.73 to 6.34 . It is noted that the drainage density values of all the micro watersheds exhibit positive correlation with the stream frequency suggesting that there is an increase in stream population with respect to increasing drainage density.

The rainfall runoff relationship for the Yagachi catchment is shown in fig 7. It is depicted that positive correlation occurs between rainfall and runoff in all the 20 micro-watersheds. The regression coefficient values for the micro-watersheds lie between 0.602 to 0.866 . The maximum weighted rainfall and runoff for the catchment was $1530 \mathrm{~mm}$ and $184 \mathrm{~mm}$ and minimum rainfall and runoff were $779 \mathrm{~mm}$ and $42 \mathrm{~mm}$ respectively during 10 years period. It is observed that during the year 2009 maximum rainfall and runoff of $2301 \mathrm{~mm}$ and
$753 \mathrm{~mm}$ respectively have occurred in Micro-watershed 1. It is also observed that during the year 2006 in Micro-watershed 12 minimum runoff of $15 \mathrm{~mm}$ has occurred. It is depicted that positive correlation occurs between rainfall and runoff in all the 20 Micro-watersheds.

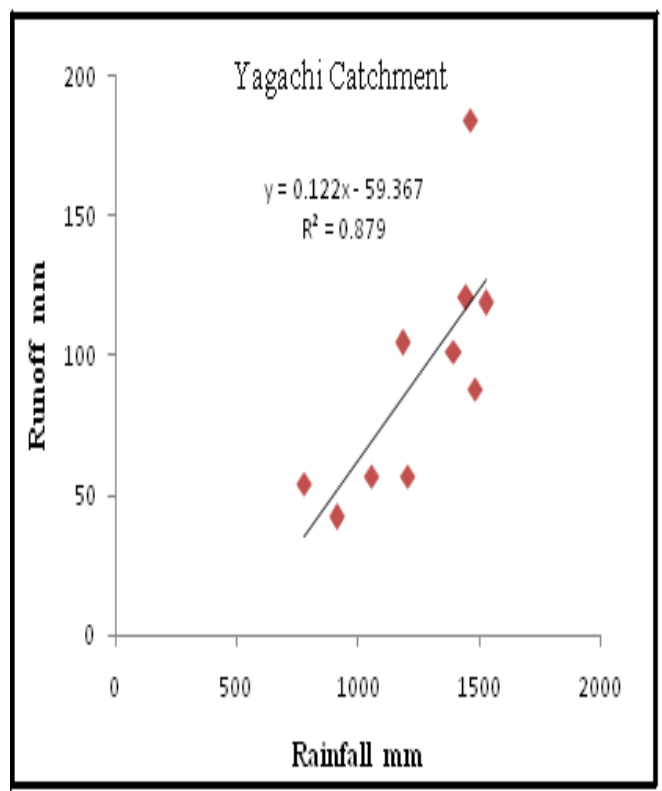

Fig. 7 Rainfall- runoff relationship of Yagachi Catchment

The model was repeated to estimate the runoff and also to find the impact of change in trend of lulc from year 2001 to 2010 on the runoff using the same rain guage data and the results observed were tabulated in Table. 3 .

Table.3 Impact on Runoff due to Change in LULC

\begin{tabular}{|l|l|l|l|l|}
\hline \multicolumn{3}{|c|}{$\begin{array}{l}\text { Comparative table showing the impact on runoff due } \\
\text { to change in LULC }\end{array}$} \\
\hline & \multicolumn{2}{|c|}{2001} & \multicolumn{2}{c|}{2010} \\
\hline Year & Rainfall & Runoff & Rainfall & Runoff \\
\hline 2001 & 1055.34 & 56.53 & 1055.34 & 40.39 \\
\hline 2002 & 915.00 & 42.18 & 915.13 & 32.63 \\
\hline 2003 & 778.52 & 54.27 & 778.52 & 41.03 \\
\hline 2004 & 1183.90 & 104.34 & 1183.90 & 75.55 \\
\hline 2005 & 1529.70 & 118.80 & 1529.70 & 80.15 \\
\hline 2006 & 1206.32 & 57.10 & 1206.32 & 37.13 \\
\hline 2007 & 1463.89 & 183.93 & 1463.89 & 140.43 \\
\hline 2008 & 1448.61 & 120.44 & 1448.61 & 85.16 \\
\hline 2009 & 1397.11 & 101.28 & 1397.11 & 69.91 \\
\hline 2010 & 1482.96 & 88.13 & 1482.96 & 61.88 \\
\hline
\end{tabular}


Table.4 Change in the trend of LULC from 2001 to 2010

For Yagachi Catchment

\begin{tabular}{|l|l|l|l|}
\hline \multicolumn{2}{|l}{ Abstract of LULC for Yagachi catchment } & \multicolumn{2}{l}{} \\
\hline $\begin{array}{l}\text { SI } \\
\text { No }\end{array}$ & LULC-Level-3 & Area(2001) & Area(2010) \\
\hline 1 & Agricultural Plantation & 171.718 & 164.822 \\
\hline 2 & Barren Rocky / Stony Waste / Sheet Rock Area & 2.185 & 0.164 \\
\hline 3 & Degraded Forest & 0.832 & 4.671 \\
\hline 4 & Dense Grass land / Grazing land & 1.644 & 12.953 \\
\hline 5 & Fallow land & 3.978 & 8.92 \\
\hline 6 & Forest Plantations & 1.945 & 0.161 \\
\hline 7 & Habitation with Vegetation & 5.436 & 40.007 \\
\hline 8 & Kharif + Rabi (Double Crop) & 48.822 & 38.953 \\
\hline 9 & Kharif crop & 253.14 & 192.87 \\
\hline 10 & Lake / Tanks & 12.41 & 2.745 \\
\hline 11 & Reservoir/Rivers/streams & 2.016 & 0 \\
\hline 12 & Land with scrub & 12.465 & 10.987 \\
\hline 13 & Mining / Industrial Wasteland & 0.074 & 0 \\
\hline 14 & Mixed Vegetation & 4.01 & 5.89 \\
\hline 15 & Moist \& Dry Deciduous Dense Forest & 4.712 & 3.921 \\
\hline 16 & Moist \& Dry Deciduous Open Forest & 1.243 & 6.723 \\
\hline 17 & Town / Cities/Villages & 20.58 & 6.328 \\
\hline 18 & Tree Groves & 12.282 & 37.588 \\
\hline 19 & Tanks without water & 0 & 21.791 \\
\hline & TOTAL & 559.493 & 559.494 \\
\hline
\end{tabular}

\section{CONCLUSIONS}

The catchment is well distributed with tanks which are basically fed by rain water and the perennial streams which find its flow due to regenerated irrigation, subsurface flow and due to presences of Western Ghats from where river Hemavathi originates. The study has demonstrated that, remote sensing and GIS has advantages in estimating runoff from large and ungauged catchments. The drainage density obtained from the study shows that the catchment is a coarse textured catchment. Curve number estimation using remotely sensed data has been shown to be more cost effective than conventional procedure. The study will serves as an input for the management of natural resources available within the watershed. The maximum and minimum runoff estimated for individual micro watershed during the period 2001 to 2010 is $2310 \mathrm{~mm}$ and $15 \mathrm{~mm}$ respectively. The observed inflow is more than the estimated runoff, this is mainly due to continuous irrigation, seepage from the agricultural land and lateral flow causing in the catchment area.

\section{REFERENCES}

[1]. Horton, R. E (1932) Drainage basin characteristics, Transaction of the American Geophysical Unions, 13, pp. 350361.

[2]. McCuen, R. H (1982), A Guide to Hydrologic Analysis using SCS Methods, Prentice Hall Inc., New Jersey.

[3]. Nageshwar Rao. K, Swarna Latha. K ., Arunkumar. P and Harikumar, M (2007) Marphometric Anlysis of Geostani River Basin in Andhra Pradesh State, India usning Spatral Information Technology, Indian Journal of Geomatics and Geosciences, Vol-1, No.1, pp. 179-187. 
[4]. Ponce, M Victor and Hawkins H Richard (1996) Runoff Curve Number; Has it Reached Maturity Journal of Hydraulic Engineering, ASCE (1), pp. 11- 19.

[5]. Rama Prasad, Sridharan, K., and Vedula, S (1993), Runoff Estimation for small ungauged catchments, Report Prepared for Chief Engineer (Minor Irrigation), Govt- of Karnataka, India.

[6] Ravikumar, A. S, (2001), Water Balance Components from Field Studies using Remote Sensing and Geographical Information System, Ph. D Thesis, Indian Institute of Science, Bangalore

[7].Soil Conservation Services, (1972), National Engineering Handbook, Hydrology, Section 4, Chapter 4 to 10.

[8].Strahler, A. N (1964) Quantitative Geomorphology of Drainage basin and channel Network. Hand book of Hydrology edited by Ven Te Chow, McGraw Hell section 411.

[9].Stube, M. M and Johnston, D. M (1990) Runoff Volume Estimation Using SCS Techniques, Water Resources. Bull., 26 (4), pp. 611-620.

[10].Ven Te Chow (1982) Handbook of Applied Hydrology, McGraw Hill Book Company. 